\title{
Consideration of Obscene Speech in Prejudication in US Constitution
}

\author{
Wenjuan Huang \\ School of Law, Shandong University of Technology \\ Zibo 255049, Shandong, China \\ Fang Zong \\ School of Law, Shandong University of Technology \\ Zibo 255049, Shandong, China
}

\begin{abstract}
Under the dimension of US constitutionalism, freedom of speech is imprescriptible, while limitation to obscene speech in judicial practice becomes exception of the stipulation of US Constitution "prohibiting laying down the law". Furthermore, coordination of conflicts between the two turns to be the target sought by the Federal Supreme Judicial Court. Prejudication on games between the two by the Supreme Court approximately went through three periods, namely, "Hicklin Norm" period, "Roth Norm" period and "Miller Norm" period, transiting from the standards of "those who are most likely to be influenced", and "sort of obscenity", to standards of "normal people" and "totally not redeeming social value", and then to the standard of "serious value". The Supreme Court attempted to seek for a balance between implementation of freedom of speech guaranteed by the Constitution and obscene speech.
\end{abstract}

Keywords: Obscene speech, Hicklin Norm, Roth Norm, Miller Norm

US is a nation in which freedom is highly upheld, and the characteristics of its constitutional system are to establish and guarantee individual freedom and right, and to define and restrict authority and privilege of the government. It is definitely stipulated in the First Amendment of US Constitution, the Congress prohibits formulating a law related with any of the following items, that is, to establish a religion or prohibit freedom of worship; to restrict freedom of speech or freedom of publication; to restrict the right of peaceful assembly and the right of petition to the government (namely, the stipulation of "prohibiting laying down the law")

However, American government falls into perplexity in judicial practice for the extensive protection of the freedom of speech: Whether obscene speech falls within the scope of protection of the First Amendment? How to define obscene speech? ... All these problems have always perplexed Lord Chancellors with high intelligence in the Federal Supreme Judicial Court, and they promoted American judicial circles' tolerance to and respect on freedom of sexual expression with legal precedents one by one, with severe games behind. During judicial practice for more than a hundred years, America has gone through approximately three historical periods in the judgment on obscene speech, that is, "Hicklin Norm" period, "Roth Norm" period and "Miller Norm" period.

\section{1. “Hicklin Norm” period}

American laws are deeply influenced by the tradition of the British Common Law. The first definition on obscenity by US Courts took its source in the case of Hicklin sued by the Queen in 1868. In the case, British Royal Family expounded how to assert obscenity as for the books about anti-Catholicism with sexual content distributed by Hicklin.

Hicklin Case confirmed the fundamental principle of obscenity: firstly, any publication should not offend or violate those who were mostly likely to be influenced, including juveniles, adults with ill tendency and all lower class people. Secondly, whether a publication was obscene was not based on the entire content, but based on part of its content. If part of a publication was confirmed as obscenity, then the entire publication would be asserted as obscenity. Thirdly, assertion of obscenity was based on the intention of a publication, and simultaneously, any works that might contain unclean and obscene thought should be prohibited. What judges took into consideration was reflection after reading a publication, totally regardless of whether it would actually result in any antisocial behavior.

This norm was universally applied in US until 1930s. However, during that period, all courts held different views upon application of this norm, and the general direction was to abide by Hicklin principle, but to negate the right of freedom of speech endowed by the First Amendment of the Constitution. US Federal Supreme Judicial Court took a strict attitude towards any obscene speech. According to the Lord Chancellor F. Murphy of the US Federal Supreme Judicial 
Court, "indecent, obscene, profane, infamatory, contemptuous or aggressive speeches" fell within the scope of speeches without any social value, so they should not be under protection of the Constitution, because such a sort of speeches would not constitute any important ingredient of expression of a thought; from the perspective of seeking for truth to benefit the society, their social value was infinitesimal, so the social interest in terms of order and morality went far beyond their social value. Thus, it is obvious to find out the method of American judicial circles to "hate bitterly" obscene speech and the way of "cutting at one stroke".

\section{2. "Roth Norm" period}

It was in 1957 when Roth sued United States that the Federal Supreme Judicial Court really overthrew "Hicklin Norm". In this case, the Supreme Court formally made an assertion on definition of obscenity for the first time, and required to make clear the standard of obscene publication. The Supreme Court began to attempt to define "obscene speech", and "made a distinction" among such a sort of publications, but not "totally repudiating" as before.

The Judge Brennan publicly discarded Hicklin principle and emphasized the new principles to assert obscenity, namely, whether it exerted influences upon normal people, whether it adapted to contemporary community standard; and whether it would stimulate the lust if the entire subject of a publication was considered. That is, firstly, a publication should be asserted to be obscene, and whether it would arouse the lust or any unclean thought, which should be based on the standard of normal people in a community, which was judged on influences of a publication upon all people it contacted, but not influences on a particular group of people in the community. Secondly, a publication should be assessed in terms of its whole thought, but not merely a certain detail. Furthermore, the assessment should be based on the contemporary community standard, because with changes of the times, people held a more and more tolerant attitude towards sex. Therefore, definition on obscenity should be dynamic.

This viewpoint diminished constraints on publications, and enlarged the scope of protection upon them. However, at that time, it aroused doubt from quite a large majority of people, so it was difficult for it to be adapted for quite a long time. In 1959, Kingsley International Film Company sued the Board of Directors of New York State University, which was the first case to apply Roth Case principle. This case overthrew prohibition on the film "Lady Chatterley's Lover", approved film projection license, asserted the film was no longer within the scope of obscene publications considering the whole purpose, and obviously broadened scope of examination on obscene publications. In addition, the case provided guarantee for the Supreme Court to protect freedom of speech pursuant to the Constitution and to protect publications with different value, standards and ethical concepts. However, Kingsley Case did not make a further discussion on the definition of obscenity established in the Roth Case and was ambiguous about definition of obscenity, which was an obvious limitation in the case.

However, newly emerging issues challenged Roth Norm, such as, how to define meaning of "community", how to make a distinction between "normal people" and "ordinary people" and how to establish value of obscene publications.

In the Case of Day sued by Manual Company in 1962, Manual Company published a special magazine for berdaches which was attached with photos of completely naked male models, and was suppressed by the Post Office. Finally, the Supreme Court was in support of this publication behavior. The Lord Chancellor Harlan pointed out that this magazine was not obscene. According to him, the so-called obscenity was obviously disgusting and would arouse the lust of one, but in this case, the publication merely involved part of people, namely, berdaches, not all citizens. Furthermore, he pointed out, the standard of "graceful norm of contemporary community" applied to the whole country, but American society was a nation with diversified culture, so there didn't exist a unified community ethical norm, which, as a matter of fact, had enlarged the connotation of "community" randomly, and had diminished sphere of application of the definition on obscenity in the case of Roth. This, without doubt, was to protect freedom of speech to a greater extent on the part of some special citizens. Afterwards, in the Case of Jacobellis v. Ohio in 1964, the Lord Chancellor Brennan reaffirmed that the connotation of "community" should be judged according to the norm all over the country. However, the Chief Justice Warren still insisted on Roth principle, and thought community standard was not a nationwide standard at all and there didn't exist a nationwide standard. According to him, even if such a situation happened, the task of the Supreme Court was to coordinate conflicts of rights among communities within the scope of the society and individuals. As a matter of fact, what Warren insisted on was a local community standard. Controversy on the connotation of "community" among these judges led to ambiguous assessment on obscene speeches later.

In the Case of New York State sued by Mishkin in 1966, the Supreme Court once again was confronted with difficulties to define "ordinary people" and "normal people". According to Mishkin, the publication merely aroused interest of particular groups of people and didn't arouse the lust of ordinary people, not even leading to disgust of ordinary people, so it didn't violate the law. Since Roth Case didn't make clear a definite distinction between "ordinary people" and "normal people", in practical operation, the similar result was caused as in Hicklin Case (that is, almost all people were taken as a standard). However, the concept of ordinary people changed continually with tolerance of the society, so definition of justice on "ordinary people" and "normal people" should also be upgraded, while the standard of "ordinary people" applied in this case was still the one applied in the Hicklin Case period several decades ago, namely, the 
standard of "people who were most likely to be influenced". This, as a matter of fact, diminished the scope of protection of obscene publications by the Constitution.

Brennan emphasized that, the only reason why obscene publications were excluded from the First Amendment was that obscene publications could not redeem social importance. However, in fact, some publications with sexual description were not totally without any social value. In the "Memoirs of a Woman of Pleasure" by John Cleland which sued the Attorney General of Massachusetts and the Case of New York State sued by Redrup, Brennan pointed out, a book should not be prohibited unless it was totally without any social value, even if it was proved to have aroused the lust. That is, so long as a publication was proved to have a wee bit of social value, it would be under protection of the Constitution, and should not be prohibited with the excuse of arousing the lust and obviously violating community ethical standard, which obviously discarded the standard of Hicklin Case, namely, people who were most likely to be influenced.

Thus, it can be seen, there exist great distinctions between "Roth" Case and "Hicklin" Case. Firstly, in the Case of "Roth", "ordinary people" were chosen as a target for assessment, whereas in the Case of "Hicklin", "people who were most likely to be influenced, including juveniles" were chosen as a target for assessment; secondly, in "Roth" Case, "the whole leading subject of a publication" was the basis of judgment, whereas in "Hicklin" Case, "obscene tendency" of a publication was the basis of judgment, that is, the entire publication would be considered obscene so long as part of its content was obscene; thirdly, in the Case of "Roth", the standard of "contemporary community" was put forward, and contemporary sexual ethical concept was employed as a measurement standard. In addition, obscenity was confined to the scope of pornography, excluding other content from the concept of obscenity, and the standard of "totally not able to redeem social importance", enlarging the scope of protection of obscene speeches. From all the above distinctions, it can be seen, in terms of protection on obscene speeches, great progress had been made in "Roth" Case compared with "Hicklin" Case, and the former exhibited justicial tolerance and gradual rationality. Of course, there still existed many problems open to be resolved, such as, definition of "community", "ordinary people" and "obscenity", etc.

\section{3. "Miller Norm" period}

Definition on obscenity had always been perplexing all judges, and, as a matter of fact, this was to define those that could not be defined at all (the Lord Chancellor Stuart). The Supreme Court headed by Warren felt pessimistic and discouraged to define on obscenity. Afterwards, the Supreme Court headed by Burger drew back from the viewpoint of guaranteeing freedom of expression in the First Amendment. Of course, it was god-given that, Burger gathered together most of opinions of the other four judges about obscenity for the first time since 1957, that is, "Miller Norm".

In 1973, Mawi. Miller from California sent five booklets to a restaurant in the NewPort Beach in this State. In the booklets, advertisements about four pornographic books and one film were posted, including photos and pictures of sexual behaviors. Receivers of the booklets reported this case to local police office, and Miller was under an accusation to violate criminal code in California, and was sentenced by local relevant authority. Finally, the Supreme Court passed the adjudication written by the Chief Justice Burger with a proportion of five to four, which required the State Court to retrial the case according to the new definition on obscenity. It was stipulated in Miller Norm, obscenity should contain the following conditions: (1). As for common people, according to contemporary local social standard, a publication can be proved to arouse obscene desire from an overall perspective; (2). Description of a publication about sexual behavior obviously violates stipulations of relevant law of local State. (3). A publication was short of serious literature, arts, political or scientific value.

It is obvious that there were differences between Miller Case and Roth Case. On one hand, the former discarded the standard of "totally not able to redeem social value" established in "Roth" Case, and it was replaced with the standard of "serious literature, arts, political or scientific value". US Constitution Scholar Hixon thought, this was obvious a throwback in terms of guaranteeing freedom of sexual expression for Constitution. According to Roth Case, so long as a publication was considered to have a wee bit of social value, it might be exempted from being regarded as obscenity. However, the current Miller Norm required a publication to prove to have serious value for itself to break away from obscenity, which caused an actual result that, most of publications about sexual expression were no longer under protection of the Constitution, but were considered obscene publications. Furthermore, judges, such as Brennan, called into question about this principle. After recollection, Brennan confirmed, the judicial tradition to define obscenity in the Case of Roth should be eliminated with decision, and should be substituted for the standard of "merely stipulating to prohibit disseminating obscene publications to juveniles or exposing in a disgusting way to dissenting adults", so as to protect juveniles and dissenting adults. It might be an optimal choice to interpret "obscenity" in such a wide and ambiguous way, but not defining "obscenity" in a rigid way.

On the other hand, it is confirmed to substitute community standard for the nationwide standard, which got strengthened in the later case of Hamling appealing United States in 1974 and the case of Smith appealing United States. In the case of Hamling, the Supreme Court emphasized, California had the authority to prohibit obscene publications with a standard applied in the State according to the Federal Constitution, and the Court allowed a jury to decide an obscene 
publication according to the standard of community. In the case of Smith, a jury also had the free discretion to determine "contemporary community standard" of "arousing the lust" and "being obviously disgusting". This standard meant that different districts in US might apply different judicial standards according to actual local situations. However, since it was "serious value" that had essential significance, as a matter of fact, the scope and width of publications about expression of sex was restricted.

In sum, from the standard of "people who were most likely to be influenced" in the case of Hicklin, to the standard of "ordinary people" and "totally not able to redeem social value" in the case of Roth, then to the standard of "serious value" in the case of Miller, US Federal Supreme Court really resorted to every conceivable means to attempt to seek for a balance between implementation of freedom of speeches guaranteed by the Constitution and freedom of sexual expression disgusted by a particular group of people. With controversy for over a hundred years, it was finally discovered that even an agreement upon definition of "obscenity" was still not reached. Just as the Lord Chancellor Douglas said, obscenity that could not be defined exactly by the Supreme Court was really a hodgepodge. Based on this elusory feature, each definition on obscenity by the judges seemed to be rational, but finally would declare bankruptcy all without exception. However, the tradition of US Liberalism called for US Government to amount to something in formulation of the law and in implementation of public policies so as to reach a balance between social interest and individual freedom. As for constraint imposed by the society on individual freedom, Mill put forward a general principle, that is, "One only need take responsibility for the part of his behaviors that involves others. His independence is absolute in terms of rights as for the part of his behaviors that merely involves himself. And he is the highest sovereign to himself and to his body and mind."

From the perspective of relation between social progress and development of human rights, social tolerance and self-restraint of human being are the two wings of a bird. Constraint of a nation on personal affairs should present a declining trend, whereas conscience and self-restraint of human kind should upsurge day by day, and become the internal factor to guarantee his rights. Therefore, administrative management is necessary to deal with the so-called "obscene speeches", but the means of participation and penetration of national rights should be changed, not completely negating blindly or "cutting even at one stroke". From the perspective of persuasion, appropriate entertainment and a healthy and positive living way should be advocated to gradually cultivate people's sentiment to appreciate gracious cultural life, to vigorously promote the concept of scientific sex education and to establish people's correct sex concept and good sex ethics. With development of the times and openness of ideology and culture, dissemination of prohibiting obscene speeches with differentiation can not only protect freedom of speeches of a particular group, but can guarantee good customs of the society and security of ideology. All in all, discussion of the scope of obscene speeches also involves the elementary proposition of constitutional system, that is, relation between national authority and right of a citizen, or limit problem of a national authority. However, delimitation to the two concepts is exactly the primary issue to be resolved in a constitutional country, and is also what a country needs to attain the harmonious state of benign recycling.

\section{References}

A Book Named John Cleland's Memoirs of a Woman of Pleasure v. Attorney General of Massachusetts, 383 u.s. 413(1966).

Bernard Schwartz. (1977). The Great Rights of Mankind. Oxford University Press. New York, pp.171-191. In 1992, US Congress, in the form of the $27^{\text {th }}$ Amendment, recovered the Second Amendment that hadn't been approved by all states previously.

Chaplinsky v. (1942). State ofNewHampshire, 315 U. S. 568[R].

Hamling v. (1974). U.S., 418 U.S. 87.

Jacobellis v. (1964). Ohio, 378 U.S. 184[R].

John. Mill. (1959). On Freedom, translated by Cheng, Chonghua. The Commercial Press, pp.10.

Kingsley Pictures Corp. v. (1959). Regents, 360 u.s. 684 [R].

Manual Enterprises v. (1962). Day, 370 u.s. 478 [R].

Mishkin v. (1966). New York, 383 u.s. 502.

Qian, Fuchen. (2005). The profound Context of The Building of American Constitutional System. Law Press China, pp.37.

Qiu, Xiaoping. (2005). Freedom of Expression --- Study on the First Amendment of American Constitution, D971. Peiking University Press, p231-232.

Qiu, Xiaoping. (2005). Freedom of Expression --- Study on the First Amendment of American Constitution, D971. Peiking University Press, pp.236. 
Qiu, Xiaoping. (2005). Freedom of Expression --- Study on the First Amendment of American Constitution, Peiking University Press, p264.

Regina v .Hicklin. (1868). L.R.3 Q.B.360.

Resrup v. (1966). New York, Austin v. Kentucky, Gent v. Arkansas, 386 U.S. 767.

Richard Hixson. (1996). Pornography and the Justices, Southern Illinois University Press, Carbondale, p.114.

Roth v. (1957). United States, 354 u.s.476 [R].

Smith v. (1977). U.S., 413 U.S. 291.

Steven Gey. (1988). The Apologetics of Suppression: the Regulation of Pomography as Act and Idea. Michigan Law Review, Vol.86, p.1572.

Thomas Emerson. (1980). First Amendment Doctrine and the Burger Court, California Law Review, Vol. 68, p.440.

William Lockhart \& Robert McClure. (1961). Censorship of Obscenity: the Developing Constitutional Standards. Minnesota Law Review, Vol. 45, p70-73.

Zhang, Shiyun. (2007). Obscenity and Freedom of Expression: Judicial Controversy and the U. S. Supreme Court Decisions. Journal of University of International Relations, No. 2. 